\title{
A Thermodynamic Study on Micelle Formation of Cationic Surfactants Derived from Different Bile Acids
}

\author{
Yau-Ichi ARaki, Tomomichi Yanagida, Mihoko Hisatomi, \\ Taira KiYota, Sannamu LeE, and Gohsuke SugIHARA \\ Department of Chemistry, Faculty of Science, Fukuoka University \\ (8-19-1, Nanakuma, Jonan-ku, Fukuoka-shi 814-0180)
}

\begin{abstract}
The synthesis of a series of new cationic bile salt derivatives (CBADs), the hydrochloride salts of ethylenediamine monocholate $(\mathrm{EdaC})$, ethylenediamine monodeoxycholate (EdaDC), ethylenediamine monochenodeoxycholate (EdaCDC) and ethylenediamine monoursodeoxycholate (EdaUDC) was carried out and aqueous solution properties such as critical micellization concentration (CMC) and degree of counterion binding $(\beta)$ were determined by means of surface tension measurement (drop volume method) at different temperatures from $10^{\circ} \mathrm{C}$ to $50^{\circ} \mathrm{C}$ (at every $10^{\circ} \mathrm{C}$ ). Surfactant properties of CBADs such as micellization, $\beta$ and surface activity were noted essentially the same (except for EdaC) as those of the corresponding free bile salts, while CBADs have greater membrane permeability and biomembrane perturbation ability compared to the sodium salts of free bile acids.

Examination of added salt effect on CMC indicated the degrees of counterion binding to generally be 0.25 (very low compared to alkyl chain type surfactants) not only for CBADs but free and conjugated bile acid salts as well depending little on temperature. Thermodynamic parameters subsequent to micellization $\left(\Delta G_{\mathrm{m}}^{0}, \Delta H_{\mathrm{m}}^{0}\right.$, and $\left.\Delta S_{\mathrm{m}}^{0}\right)$ were estimated for the respective CBADs as a function of temperature. The entropy-enthalpy compensation relationships which have in common a compensation temperature $\left(T_{C}\right)$ of 300 were found to hold for any CBAD. These parameters are discussed.

Key words : micelle formation, cationic surfactant(s), cationic bile salt(s), entropy-enthalpy compensation phenomenon, surface tension measurement(s), bile acid derivative(s), critical micellization concentration, degree of counterion binding
\end{abstract}

\section{Introduction}

Bile salts are a group of indispensable biosurfactants, a variety of which occur in living bodies of vertebrates ${ }^{1.2)}$, acting as solubilizing or emulsifying agents for absorption of dietary lipids ${ }^{3), 4)}$ or in clinical medicine as gallstone-solubilizing agents $^{4.5)}$. Moreover, their surfactant properties such as surface activity, micelle formation and solubilization are often applied to liposome preparation or membrane-bounded protein-solubilization. Thus, their analogs have so far been synthesized to understand their physiological functions and to exploit suitable membrane solubilizing agents. Almost of them, however, are anionic except for the case of cholyl amines ${ }^{6.7)}$ or

Corresponding author: Gohsuke SUGIHARA amino-substituted cholic acid analogs in steroid moiety $^{8)}$.

Of a variety of application aspects of surfactants, the membrane protein chemistry is nominated as an important application of surfactants since membrane proteins can be solubilized from an intact form only by surfactants, and their crystals cannot be grown without surfactants. Of different types of surfactants, recently, nonionic surfactants have been growing in application because they can stabilize more effectively the solubilized protein than the other types ${ }^{9}$. Most of ionic surfactants, on the other hand, have been less and less employed not only because they occasionally have a denaturing effect on membrane proteins, but also because they tend to bind too strongly, introducing an unspecified number of charged groups. In this connection, zwitterionic derivatives of bile acids, 
CHAPS (3-[(3-cholamidopropyl) dimethylammonio]-1-propanesulfonate hydrate) and CHAPSO (3-[(3-cholamidopropyl) dimethylammonio]-2hydroxy-1-propanesulfonate) have been developed as the membrane solubilizing agents. Nevertheless, bile salts are the most commonly used surfactants in membrane solubilization, protein isolation and reconstitution ${ }^{10}$.

As is well known, bile salts have a steroid skeleton instead of an alkyl chain as a hydrophobic moiety. The interior (core) of the micelle is therefore less flexible than that of alkyl surfactants ${ }^{11)}$. Thus, the interaction mode of bile salts with lipid bilayer is different from that of common alkyl chains surfactants. Therefore, sodium salts of deoxycholic acid and cholic acid are well-known as mild membrane solubilizing agents. However, they easily precipitate in acidic $\mathrm{pH}$ region so that their use has been restricted to the solution above $\mathrm{pH} 7$ and 7.5, respectively. Previously, we have synthesized two kinds of new cationic surfactants derived from bile acids (CBADs), the hydrochloride salts of ethylenediamine monodeoxycholate (EdaDC) and ethylenediamine monocholate $(\mathrm{EdaC})$, and investigated their physicochemical and biological properties together with the possibility of application as crystallizing agents for membrane proteins. In the previous study for these two surfactants, the following findings have been reported ${ }^{10)}$.

1) The data of CMCs, dye-release from liposomes, and biomembrane perturbation ability indicate that the two cationic bile acid derivatives have the highest surfactant ability, followed by the corresponding taurine-conjugated bile acid salts, taurodeoxycholate (TDC) and taurocholate (TC). The free bile acid salts, deoxycholate (DC) and cholate (C) showed the lowest activity for the membrane perturbation.

2) The concentrations leading to the large increase in the membrane permeability are significantly lower than the CMCs of these surfactants.

In the present paper, we report a systematical thermodynamic study on four species of cationic surfactants ; EdaCDC (derived from chenodeoxycholic acid), EdaUDC (derived from ursodeoxy-
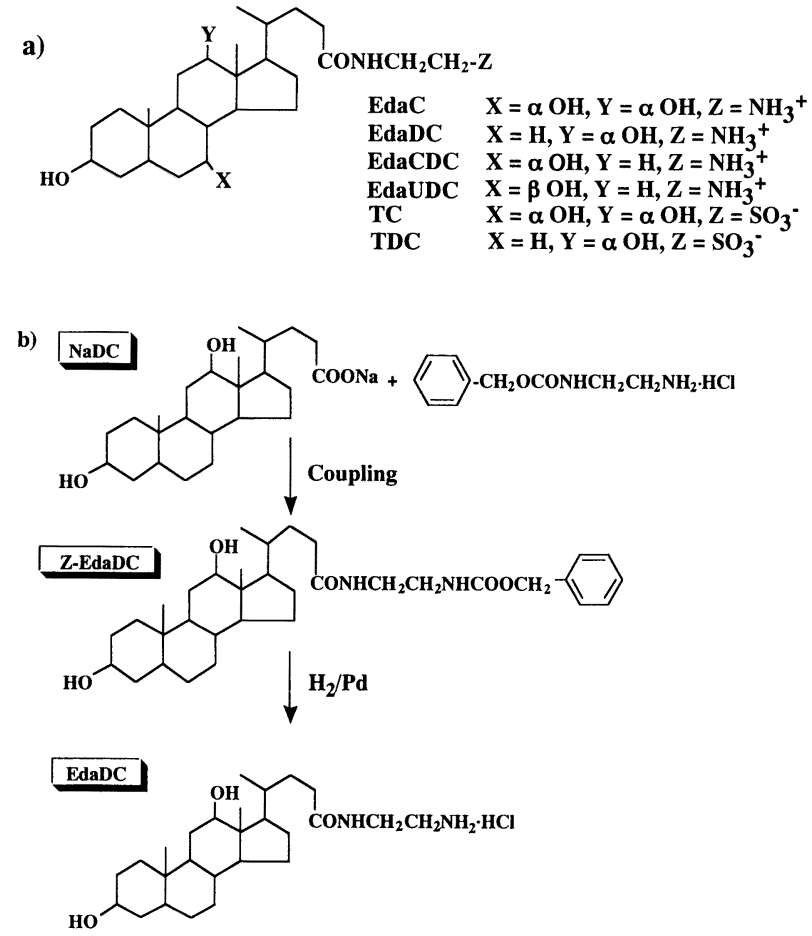

Fig. 1 (a) Molecular Structure of Cationic Bile Acids (CBADs) and Corresponding Taurine Conjugates and (b) Their Synthetic Route of EdaDC, as an Example. 
cholic acid), EdaDC and EdaC. Chemical structure formulae of different bile acids and CBADs are shown in Fig. 1.

\section{Experimental}

\section{$2 \cdot 1 \quad$ Materials}

Ethylenediamine monocholate (EdaC), ethylenediamine monodeoxycholate (EdaDC), ethylenediamine monochenodeoxycholate (EdaCDC) and ethylenediamine monoursodeoxycholate (EdaUDC) were synthesized by basically similar procedure as described below for EdaDC from the respective $\mathrm{NaC}, \mathrm{NaDC}, \mathrm{NaCDC}$ and NaUDC which were donated by Tokyo Tanabe Co. Ltd., Tokyo, Japan and ethylenediamine monocarbobenzoxylate.

Sodium chloride $(\mathrm{NaCl})$ and ethylendiamine monocarbobenzoxylate were purchased from Nacalai Tesque, Inc. Kyoto, Japan. $\mathrm{NaCl}$ was roasted at $973 \mathrm{~K}$ to remove any surface active impurities. The thrice-distilled water was used as the solvent.

\section{$2 \cdot 2$ Synthesis of EdaDC as an example}

An example of synthetic route is indicated in Fig. 1. To a chilled solution of $\mathrm{NaDC}(2.07 \mathrm{~g}, 5$ $\mathrm{mM})$, ethylene-diamine $\cdot$ monocarbobenzoxylate hydrochloride $(1.15 \mathrm{~g}, 5 \mathrm{mM})$ and HOBT $(1.01 \mathrm{~g}$, $7.5 \mathrm{mM}$ ) in dichloromethane was added 1-ethyl-(3dimethylaminopropyl) carbodiimide hydrochloride $(1.44 \mathrm{~g}, 7.5 \mathrm{mM})$. The solution was stirred for 2 $\mathrm{h}$ at $0^{\circ} \mathrm{C}$ and then stood overnight at room temperature. The oily residue after evaporation of solvent was dissolved in ethyl acetate-water and then the organic layer was successively washed with $4 \% \mathrm{NaHCO}_{3}, 10 \%$ citric acid and water, followed by drying over $\mathrm{Na}_{2} \mathrm{SO}_{4}$. After evaporation of the solvent, the residual oil was triturated to give semi-crystals. The crystals were dissolved in methanol containing hydrochloride and then hydrogenated over palladium black. After filtration of the catalyst, the filtrate was crystallized by adding diethyl ether. [Yield, $2.17 \mathrm{~g}(92 \%)$; m.p. 225-227 ${ }^{\circ} \mathrm{C}$. Anal. : C, $63.72 ; \mathrm{H}, 9.62 ; \mathrm{N}, 5.91$ (\%). Calcd. for $\mathrm{C}_{28} \mathrm{H}_{47} \mathrm{O}_{3} \mathrm{~N}_{2} \mathrm{Cl}: \mathrm{C}, 63.98 ; \mathrm{H}, 9.91$ ; N, $5.74(\%).]^{10)}$

\section{$2 \cdot 3$ Surface tension measurements}

For thermodynamic analysis, the surface tension data were strictly obtained for each solution as a function of temperature, which was controlled by the use of a thermostated bath with an accuracy of $\pm 0.05 \mathrm{~K}$ at every five temperature ranging from $10^{\circ} \mathrm{C}$ to $50^{\circ} \mathrm{C}$. The surface tension $(r)$ measurements were performed by means of the same drop volume technique using a glass dropping tip as described previously by Uryu et al. ${ }^{12)}$. Each drop was permitted to stand for up to $15 \mathrm{~min}$. in order to attain the adsorption equilibrium. (It has been beforehand confirmed for the sample solution to attain its adsorption equilibrium in $15 \mathrm{~min}$ and to give usually a stabilized value around $15 \mathrm{~min}$.) Each measured point was determined from averaging three or four measurements.

$2 \cdot 4$ Determinations of CMC and degree of counterion binding $(\beta)$.

All the CMC data including those of the systems containing added salt were obtained from the drop volume technique. The CBADs solutions at the respective concentrations with or without added $\mathrm{NaCl}$ were batchwise prepared from a concentrated CBAD's stock solution, the concentrations of which were set up so as to cover 8 - 10 measured points above and below the critical micellization concentration (CMC) estimated by a preparatory experiment. The stock solutions with added $\mathrm{NaCl}$ were prepared using aqueous $\mathrm{NaCl}$ solutions at the respectively fixed concentrations. The degree of counterion binding $(\beta)$ was determined from the

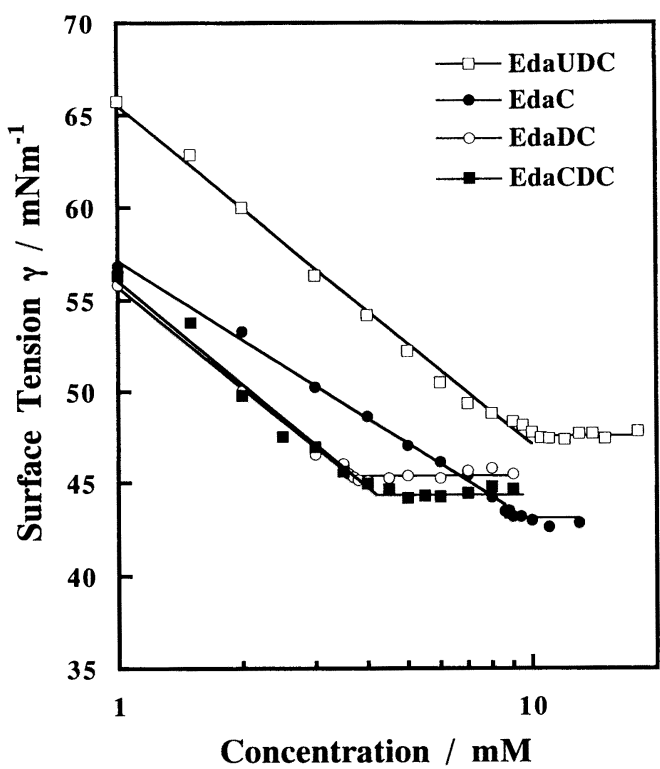

Fig. 2 Surface Tension vs. Concentration Curves of Cationic Surfactants Derived from Bile Acids at $30^{\circ} \mathrm{C}$. 
effect of added salt $(\mathrm{NaCl})$ on $\mathrm{CMC}$ at each temperature by applying the Corrin-Harkins plot.

\section{Results and Discussion}

The surface tension of cationic bile acids in aqueous solution was measured by the drop volume technique. Figure 2 shows the surface tension $(r) v s$. surfactant concentration in pure aqueous solution at $30^{\circ} \mathrm{C}$. In Fig. 2 are found concentrations giving a sharp break corresponding to the critical micelle concentrations (CMCs) at 3.6 $\pm 0.4 \mathrm{mM}$ for EdaDC, $9.0 \pm 0.3 \mathrm{mM}$ for EdaC, 4.5 $\pm 0.3 \mathrm{mM}$ for EdaCDC and $9.0 \pm 1.0 \mathrm{mM}$ for EdaUDC, and the surface tensions above CMC are $44.5 \mathrm{mNm}^{-1}$ (EdaDC) and $43 \mathrm{mNm}^{-1}(\mathrm{EdaC})$, $44.5 \mathrm{mNm}^{-1}$ (EdaCDC) and $48 \mathrm{mNm}^{-1}$ (EdaUDC), respectively. The curves of EdaC and EdaDC were reproduced from the previous report ${ }^{10)}$. (But, recently it was found that the plots were wrong in the absolute value of $\gamma$. This error was kindly pointed out by Kratohvil, Clarkson Univ. In the present figure, corrected $\gamma$ values are plotted.) It is interesting that EdaUDC has shown the lowest surface activity and the highest CMC and that these properties are not so different from those of sodium ursodeoxycholate (NaUDC : $\mathrm{CMC}=10.4 \mathrm{mM}, \gamma=\mathrm{ca} .48 \mathrm{mNm}^{-1}$, measured by the drop volume method at $30^{\circ} \mathrm{C}$, unpublished data). On the otherhand, EdaC shows stronger surface activity than those of sodium taurocholate ${ }^{10), 13)}$ and sodium cholate ${ }^{14)}$, although the reason cannot be interpreted yet.

Note that, in general, as for the trends in surface activity as well as CMC, the respective CBADs exhibit almost the same behaviors of the corresponding free bile acid sodium salts, indicating that the change of head group from carboxyl group to ethylendiamine does hardly influence the basic properties such as CMC and surface activity.

Looking at the curves in the range below CMC, EdaDC, EdaCDC and EdaUDC have a rapid decrease compared with EdaC. The surface excess (adsorption amount per unit area), $\Gamma$, may be calculated according to the Gibbs adsorption isotherm :

$$
\Gamma=-\frac{1}{2 R T} \cdot \frac{\mathrm{d} \gamma}{\mathrm{d} \ln C}
$$

where $R T$ is the product of the molar gas constant with the Kelvin temperature. And also the mean molecular (occupation) surface area, $A_{\mathrm{m}}$, can be
Table 1 Limiting Area (Am) Values of Free, Conjugated Bile Acids ${ }^{\mathrm{a}}$ and CBADs.

\begin{tabular}{cc}
\hline Cationic surfactant & $\mathrm{Am} / \mathrm{nm}^{2}$ \\
\hline EdaC & 1.35 \\
EdaDC & 1.05 \\
EdaCDC & 1.08 \\
EdaUDC & 1.05 \\
\hline Bile acid & \\
Free & \\
\hline \hline CA & $1.50^{(13,37)}$ \\
DC & $1.18^{(37)}$ \\
CDC & $1.40^{(13,37)}$ \\
UDC & $1.23^{(13,37)}$ \\
Conjugate & \\
\hline \hline GCDC & $1.17^{(38)}$ \\
GUDC & $1.12^{(38)}$ \\
TCDC & $1.12^{(38)}$ \\
TUDC & $1.09^{(38)}$ \\
\hline a References are indicated in parentheses.
\end{tabular}

calculated from the following equation :

$$
A_{\mathrm{m}}=\frac{1}{\Gamma \times L}
$$

where $L$ denotes the Avogadro's number. The $A_{\mathrm{m}}$ values were estimated as $1.05 \mathrm{~nm}^{2}, 1.08 \mathrm{~nm}^{2}, 1.05$ $\mathrm{nm}^{2}$ and $1.35 \mathrm{~nm}^{2}$ for EdaDC, EdaCDC, EdaUDC and $\mathrm{EdaC}$, respectively (See Table 1). These data clearly show that trihydroxyl bile salt, $\mathrm{NaC}$ and its derivative EdaC floating flat on the water surface occupy a wider surface area per molecule than the other CBADs from dihydroxyl cholanoic acids, and that the latter ones have a similar occupation area. Previously, from the monolayer studies were evaluated at $25^{\circ} \mathrm{C}$ the limiting surface areas for deoxycholic acid (DC), chenodeoxycholic acid (CDC), ursodeoxycholic acid (UDC) and cholic acid $(\mathrm{CA})$ as $\left.1.18 \mathrm{~nm}^{2}{ }^{15}\right), 1.40 \mathrm{~nm}^{2}, 1.23 \mathrm{~nm}^{2}$ and $1.50 \mathrm{~nm}^{2}{ }^{16)}$, respectively. The present results are in agreement with those from monolayer studies in the trend except for CDC, but, in general, the surface areas are a little narrower than those determined from the monolayer study.

Next, the surface tension data as shown in Fig. 2 enabled us to determine easily the CMC at the respective temperatures. The $\mathrm{CMC}$ as a function of temperature is demonstrated for the present CBADs in Fig. 3. It is interesting that the present four cationic surfactants have a minimum at $25 \sim$ $30^{\circ} \mathrm{C}$ as have been observed for common surfactants $^{17) \sim 19)}$. Based on the temperature dependence data, let us try to analyze the data thermodynamically as the following. 


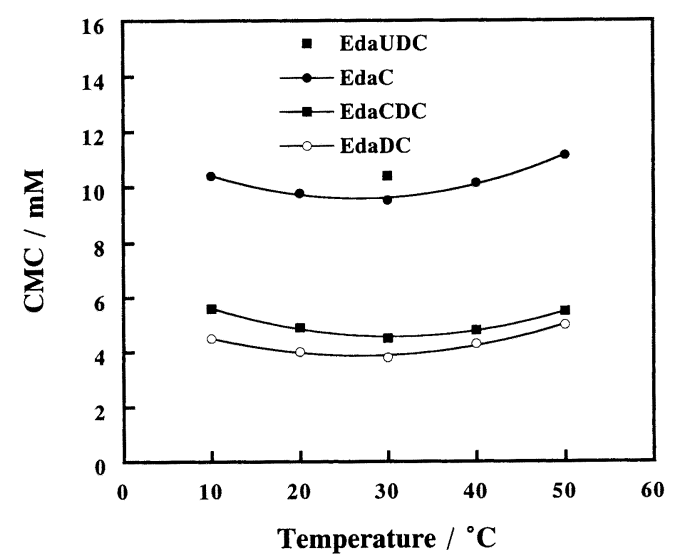

Fig. 3 CMC vs. Temperature Curves of Various Cationic Surfactants Derived from Bile Acids.

The standard Gibbs energy change upon micelle formation $\Delta G_{\mathrm{m}}^{0}$ is expressed as the following relations applying the mass action model (MAM) and the 'charged' phase separation model (PSM) in Eqs. 3 and 4, respectively, if CMC is refereed to as $X_{\mathrm{cmc}}$ (CMC is expressed in mole fraction in the solution).

$$
\begin{aligned}
\Delta G_{\mathrm{m}}^{0}= & -R T\left[\frac{1}{n} \ln \left[0.04 X_{\mathrm{cmc}} / n\right]\right. \\
+ & \left.\ln \left(0.96 X_{\mathrm{cmc}}\right)+\beta \ln \left(0.96 X_{\mathrm{cmc}}\right)\right] \\
& (\mathrm{MAM}) \\
\Delta G_{\mathrm{m}}^{0}= & R T\left[(1+\beta) \ln X_{\mathrm{cmc}}\right] \quad(\mathrm{PSM})
\end{aligned}
$$

where $n$ is the aggregation number and $\beta$, the degree of counterion binding ${ }^{20), 21)}$. The factors 0.96 and 0.04 in Eq. 3 are given by Moroi (Eq. 4.23 in ref. 21) to systems having a low aggregation number around 10 , and those the $n$ of which is more than 50 are given 0.98 and 0.02 respective$1 \mathrm{y}^{20)}$. The former equation requires a knowledge of aggregation number $n$ in addition to that of the degree of counterion binding $(\beta)$, and has been known to be more strict than the latter ${ }^{21)}$. However, when aggregation value $n$ is sufficiently large (larger than several tens) the MAM becomes approximately coincident with the PSM $^{21}$.

According to Moroi ${ }^{21)}$, Eq. 3 has been given for ionic surfactants as :

$$
\begin{aligned}
\Delta G_{\mathrm{m}}^{0}= & R T\left[(1+\beta) \ln X_{\mathrm{cmc}}\right. \\
& \left.+\frac{1}{n} \ln 2 n^{2}(1+\beta)\right]
\end{aligned}
$$

If the micelles of Eda series surfactants could have nearly the same aggregation number as those of free bile salts, this might be estimated as ca. 10 for EdaDC or EdaCDC ${ }^{22 a)}$, (and according to the recent finding for taurine conjugates of $\mathrm{DC}, \mathrm{CDC}$ and UDC by Murata from the X-ray scattering study ${ }^{22 \mathrm{~b})}$ ), and $\beta$ is taken as 0.22 at $30^{\circ} \mathrm{C}$ (as is indicated later and in Table 2 ) the 2 nd term (related to $n$ ) in Eq. $3^{\prime}$ gives as :

$\Delta G_{\mathrm{m}}^{0}($ from the $n$ related term $)=1.4 \mathrm{kJmol}^{-1}$. This means that the resultant $\Delta G_{\mathrm{m}}^{0}$ value from PSM is lower (larger in the negative $\Delta G_{\mathrm{m}}^{0}$ value) by 1.4

\begin{tabular}{|c|c|c|c|c|c|c|}
\hline $\mathrm{T}$ & $\mathrm{np} .\left({ }^{\circ} \mathrm{C}\right)$ & $\mathrm{CMC}(\mathrm{mM})$ & $\beta$ & $\Delta G_{\mathrm{m}}^{0}\left(\mathrm{kJmol}^{-1}\right)$ & $\Delta H_{\mathrm{m}}^{0}\left(\mathrm{kJmol}^{-1}\right)$ & $\Delta S_{\mathrm{m}}^{0}\left(\mathrm{JK}^{-1} \mathrm{~mol}^{-1}\right)$ \\
\hline \multirow[t]{5}{*}{ EdaDC } & 10 & 4.5 & 0.232 & -27.3 & 10.2 & 133 \\
\hline & 20 & 4.0 & 0.226 & -28.5 & 3.9 & 111 \\
\hline & 30 & 3.8 & 0.220 & -29.5 & -1.9 & 91 \\
\hline & 40 & 4.3 & 0.235 & -30.4 & -7.4 & 73 \\
\hline & 50 & 5.0 & 0.237 & -31.0 & -12.6 & 57 \\
\hline \multirow[t]{5}{*}{$\mathrm{EdaCDC}$} & 10 & 5.6 & 0.232 & -26.7 & 12.4 & 138 \\
\hline & 20 & 4.9 & 0.226 & -27.9 & 6.6 & 118 \\
\hline & 30 & 4.5 & 0.220 & -29.0 & 1.3 & 100 \\
\hline & 40 & 4.8 & 0.235 & -30.1 & -3.7 & 84 \\
\hline & 50 & 5.5 & 0.237 & -30.6 & -8.4 & 69 \\
\hline \multirow[t]{5}{*}{$\mathrm{EdaC}$} & 10 & 10.2 & 0.256 & -25.4 & 8.6 & 120 \\
\hline & 20 & 9.8 & 0.256 & -26.5 & 5.0 & 107 \\
\hline & 30 & 9.5 & 0.266 & -27.7 & 1.7 & 97 \\
\hline & 40 & 10.2 & 0.269 & -28.4 & -1.5 & 86 \\
\hline & 50 & 11.2 & 0.281 & -29.3 & -4.4 & 77 \\
\hline
\end{tabular}
$\mathrm{kJmol}^{-1}$ than that from MAM.

According to the phase separation model (PSM) neglecting temperature dependence of $\beta$, the enthalpy change is given as follows.

Table 2 Thermodynamic Parameters at Various Temperatures for CBADs. 


$$
\Delta H_{\mathrm{m}}^{0}=-(1+\beta) R T^{2}\left(\mathrm{~d} \ln X_{\mathrm{cmc}} / \mathrm{d} T\right)
$$

However, it was pointed out by Mukerjee $e^{19,23), 24)}$ that it is necessary to take into account not only the temperature dependence of the CMC but that of $\beta$ as well for calculating enthalpy changes. The enthalpy change should be given as follows.

$$
\Delta H_{\mathrm{m}}^{0}=\left[\partial\left(\Delta G_{\mathrm{m}}^{0} / T\right) / \partial(1 / T)\right]_{P}
$$

Since changes in $\beta$ are incorporated in $\Delta G_{\mathrm{m}}^{0}$ values at different temperatures, $\Delta H_{\mathrm{m}}^{0}$ can be readily determined from the slope of $\Delta G_{\mathrm{m}}^{0} / R T$ vs. $1 / T$ plots $^{19)}$. This tells us that the measurement of $\beta$ is indispensable for a strict thermodynamic treatment, even though it is based on either MAM or PSM.

In order to determine the $\beta$ at each temperature, the effect of added salt $(\mathrm{NaCl})$ was examined. In Fig. 4 are shown the temperature changes of CMCs of EdaDC and EdaC determined by the drop volume technique as a function of added salt concentration. All the curves have a minimum around $30^{\circ} \mathrm{C}$ as has been observed for different ionic surfactants ${ }^{(7), 19,21), 24) \sim 27)}$. From Fig. 4 is clearly seen the added salt effect on CMC.

The curves are used for estimating the degree of counterion binding to micelles $(\beta)$ at each temperature; the $\beta$ is given from the following relations on the basis of PSM.

$$
\Delta G_{\mathrm{m}}^{0}=R T \ln X_{\mathrm{cmc}}\left(X_{\mathrm{cmc}}+X_{\mathrm{a}}\right)^{\beta}
$$

or

$$
\ln X_{\mathrm{cmc}}=\frac{\Delta G_{\mathrm{m}}^{0}}{R T}-\beta \ln \left(X_{\mathrm{cmc}}+X_{\mathrm{a}}\right)
$$

where $X_{a}$ is concentration in mole fraction of the

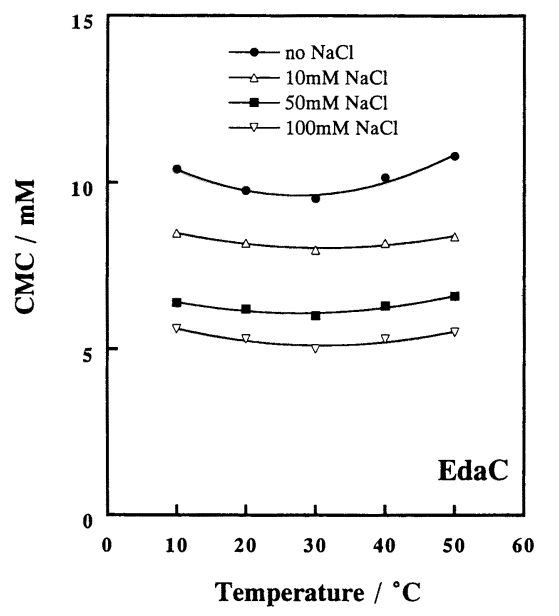

added salt in aqueous media, respectively. From Eq. 8 the $\mathrm{CMC}$ as a function of added salt concentration is known to be more concisely expressed as : $\operatorname{lnCMC}=$ const $(T, P)-\beta \ln C_{\mathrm{g}}{ }^{21)}$. This equation indicates that the $\beta$ corresponds to the slope of the curve in the plot of logarithmic $\mathrm{CMC}$ against logarithmic counterion (gegenion) concentration, i.e., $C_{\mathrm{g}}=\mathrm{CMC}+$ concn. of added salt ; this is the so called Corrin-Harkins plot. These plots showed a good linearity with a regression of more than 0.98 at each temperature (See Fig. 5). The $\beta$ values thus determined from the slopes and the CMC data (in milimolality) of the systems in pure water at the respective temperatures are tabulated in Table 2.

It should be noted that the degree of counterion binding $(\beta)$ to micelles is not much dependent on temperature for both CABDs and that the degrees themselves are very low compared with those of common hydrocarbon chain type surfactants. The $\beta$ values for $\mathrm{EdaDC}$ and $\mathrm{EdaC}$ range around 0.23 and 0.26 , respectively, over the temperature range studied. Previously, Murata et al. have determined the $\beta$ value for sodium taurodeoxycholate $(\mathrm{Na}$ TDC) (at $25^{\circ} \mathrm{C}$ in pure water) as 0.27 by using an ion selective membrane electrode ${ }^{28)}$, indicating that their result was in good agreement with that by Kratohvil et al. ${ }^{29)}$. For sodium deoxycholate (NaDC), the $\beta$ values have been found to be 0.20 and 0.25 at $\mathrm{pH} 7$ and 9 , respectively ${ }^{30)}$.

Here let us compare the $\beta$ values with that of sodium dodecyl sulfate (SDS). The $\beta$ is 0.67 for

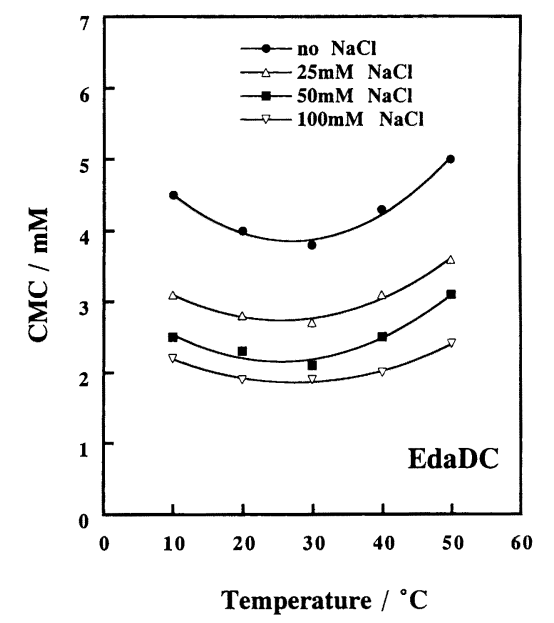

Fig. 4 Temperature Change of CMCs for the Systems of EdaC and EdaDC at Different Concentrations of Added $\mathrm{NaCl}$. 

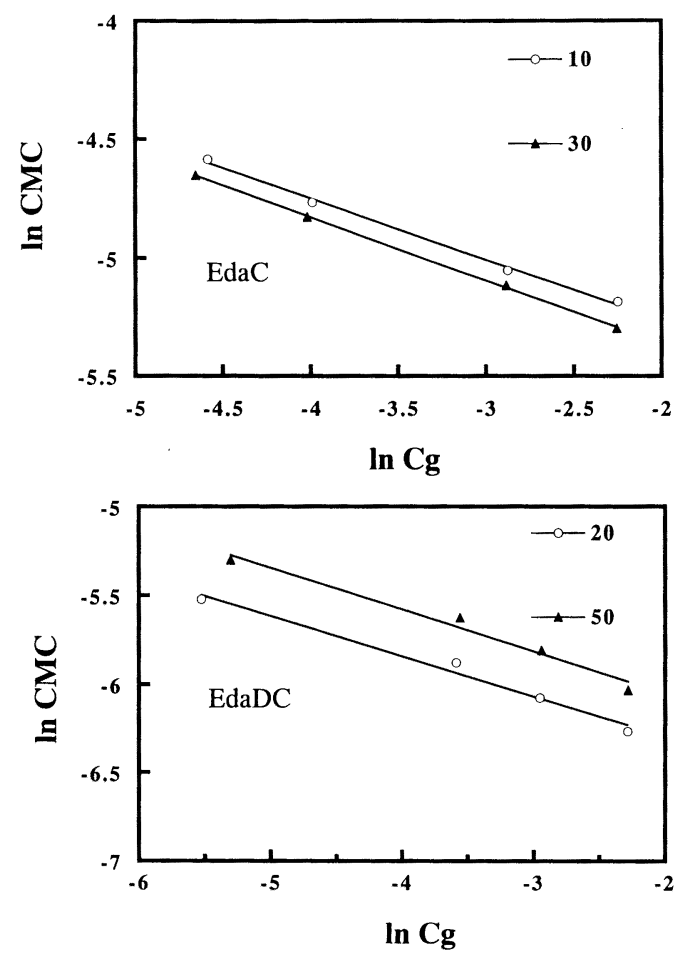

Fig. 5 Corrin-Harkins Plot for EdaC and EdaDC at Various Temperatures.

SDS micelles, hence, the values of biles salts and their derivative (NaTDC, NaDC and CSADs) seem considerably lower than that of SDS. The molecular length is almost the same for SDS and NaTDC/CBADs (ca. $22 \AA)^{28)}$, but bile salts and CBADs have a rigid-and-bulky steroid skeleton and these aggregation numbers are small compared to SDS. The aggregation number of NaTDC micelle is about $20^{31,32)}$, while according to Kratohvil et al., it ranges from 3.5 to 13.6 in the added $\mathrm{NaCl}$ concentration range of $0 \sim 0.6 \mathrm{M}^{299}$. We have a few reports that sodium salts have a dimeric form, i.e., the aggregation number is 2 , in the low concentration range ${ }^{33, b)}$ and that sodium cholate $(\mathrm{NaC})$ shows a stepwise increase in aggregation number from 2 to 16 in the concentration range up to $60 \mathrm{mM}^{34)}$. Further, there has been found that the aggregation number of the taurine conjugates of DC, CDC and UDC ranges below 10 (unpublished data) as mentioned before ${ }^{22 b)}$. The present CBADs may be probably similar in aggregation number to the respective bile salts, considering their molecular structure. Accordingly, the $n$ values are much smaller than that of SDS micelles (about $60 \sim 80$ ) at room temperature. Because of the bulkiness of steroid skeleton and the small aggregation number in addition to hydroxyl groups hydrated, the charge density at the micellar surface of bile and bile-related salts, is considered to be significantly lower than that of SDS micelles ; in other words, micelles of bile salts and CBADs do not need much contribution of electrostatic stabilization by counterion binding. (Moroi and Sugioka have shown that the $\beta$ of $\mathrm{NaC}$ is nearly zero ${ }^{34}$.)

Next, on the basis of the data in Table 2, let us make a thermodynamic calculation and discussion. First, the Gibbs energy change upon micelle formation should be examined. It was already described above in connection with the Gibbs energy, that when the aggregation number is small the estimate should be based on Eq. 3 (MAM) and that we have no correct data of the aggregation number for the present CBADs. But it was also suggested that the aggregation number ranges around 10 for CBADs and the $\beta$ values are $0.25 \sim$ 0.27 , being independent of temperature. Thus in calculation of $\Delta G_{\mathrm{m}}^{0}$, the $\beta$ for EdaCDC can be regarded as the same as for EdaDC, and the aggregation number was supposed to be 10 . However, as was described above, even if Eq. $3^{\prime}$ is applied by substituting $n=10$, the second term in Eq. $3^{\prime}$ was found to be only $1.4 \sim 1.6 \mathrm{~kJ} \mathrm{~mol}^{-1}$ for CBADs, respectively. In other words, the $\Delta G_{\mathrm{m}}^{0}$ values calculated from Eq. 4 approximately parallel those from Eq. 3'. This finding means no problem with application of Eq. 4 to the estimate of enthalpy. Therefore, the calculation of the Gibbs energy changes, $\Delta G_{\mathrm{m}}^{0}$ (listed in Table 2) was based on Eq. 4.

The well-known van't Hoff plot was applied for evaluating the enthalpy change on micelle formation, $\Delta H_{\mathrm{m}}^{0}$, from the Gibbs energy change, and the obtained curves are shown for three CBADs in Fig. 6. The curve for $\mathrm{NaC}$ is located at higher than those of dihydroxyl CBADs because of higher $\mathrm{CMC}$, while EdaDC is the lowest among three CBADs and the difference between EdaCDC and EdaDC becomes larger as the temperature is raised. This must reflect a difference in hydration of hydroxyl groups at position 7 and 12 of the steroid skeleton.

From Fig. $6 \Delta H_{\mathrm{m}}^{0}$ values were estimated and further, using the estimated $\Delta H_{\mathrm{m}}^{0}$ value, the 


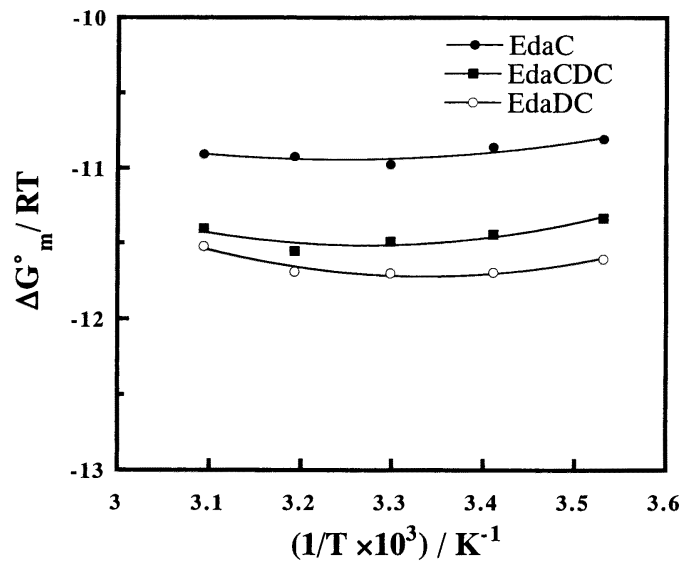

Fig. 6 van't Hoff Plot for EdaC and EdaDC.
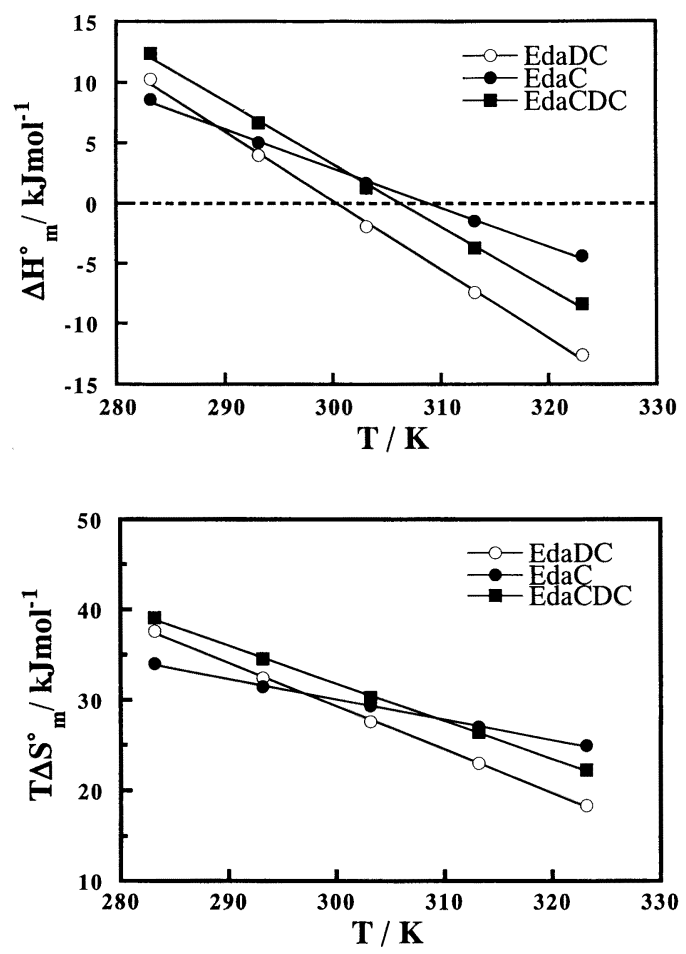

Fig. 7 Enthalpy (top frame) and Entropy (bottom frame) Term as a Function of Temperature.

entropy change $\left(\Delta S_{\mathrm{m}}^{0}\right)$ was calculated from the relation, $\Delta S_{\mathrm{m}}^{0}=\left(\Delta H_{\mathrm{m}}^{0}-\Delta G_{\mathrm{m}}^{0}\right) / T$. In the top and bottom frames of Fig. 7, $\Delta H_{\mathrm{m}}^{0}$ and the entropy term $T \Delta S_{\mathrm{m}}^{0}$ are plotted against the Kelvin temperature, respectively. Figure 7 shows that the enthalpy term changes from positive (endothermic) to negative (exothermic) at the temperature corresponding to the minimum of the CMC-

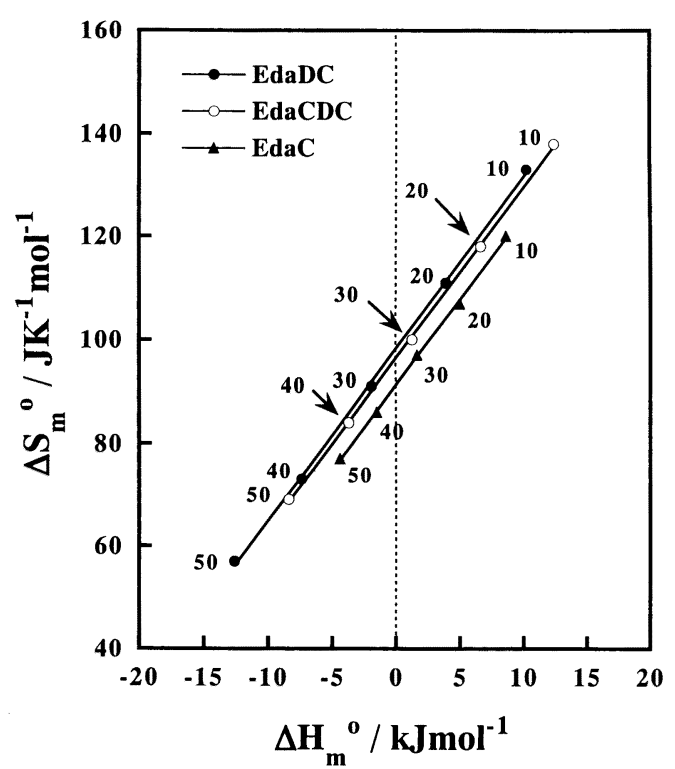

Fig. 8 The Plot of $\Delta S_{\mathrm{m}}^{0} v s . \Delta H_{\mathrm{m}}^{0}$ for CBADs. The number at each measured point indicates the temperature in ${ }^{\circ} \mathrm{C}$.

temperature curve, while the entropy term decreases monotonously with temperature.

It is noteworthy that EdaC which has three hydroxyl groups shows the smallest temperature dependence, indicating one more hydroxyl group reduces the temperature effect due to a stronger hydration. In the bottom frame of Fig. 7 the entropy term is also given for the respective CBADs. Comparing the enthalpy term with entropy term the trends are in parallel with each other. Both figures in Fig. 7 demonstrate that the water molecules around hydrophobic moiety, i.e., the so called ice likeness water molecules are more easily melt away compared with the hydration water molecules.

Concerning the relationship between entropy and enthalpy it has been observed in general that the both thermodynamic quantities compensate each other ; when the enthalpy term is less contributable to free energy, the counterpart entropy term more effectively contributes to leading the free energy to become a larger negative value and vise versa ${ }^{35)}$. This is known as the so called compensation phenomenon and also in the plot of enthalpy $v s$. entropy is seen a good linearity with a slope having the dimension of the Kelvin temperature, called the compensation temperature $^{377}$. We have investigated the entropy and 
enthalpy changes $\left(\Delta S_{\mathrm{m}}^{0}\right.$ and $\left.\Delta H_{\mathrm{m}}^{0}\right)$ upon micelle formation for more than ten surfactant species of different types and found that all species show a good linearity with almost the same slope (ca. $1 / 300 \mathrm{~K}$, e.i. the compensation temperature is 300 $\mathrm{K})$ in the plot of $\Delta S_{\mathrm{m}}^{0} v s . \Delta H_{\mathrm{m}}^{036)}$. In that paper CBADs are also included for comparison with different surfactants. Reproduced $\Delta S_{\mathrm{m}}^{0}-\Delta H_{\mathrm{m}}^{0}$ relationships are shown in Fig. 8 from which it is known that the slopes are the same but the intercepts EdaDC and EdaCDC are very close while that of EdaC is smaller. The intercept is the entropy or $\Delta S_{\mathrm{m}}^{0}=\left(1+\beta_{\mathrm{i}}\right) R \ln X_{\mathrm{cmc}}$ at $\Delta H_{\mathrm{m}}^{0}=0$, and may be regarded as a characteristic quantity for a given surfactant. The magnitude of their intercepts was found to be in line with the hydrophobic index. Discussion has been in more detail made elsewhere ${ }^{36)}$.

Finally, although surfactant properties such as surface activity, CMC and degree of counterion binding are almost similar, why are only CBADs higher in membrane permeability as well as biomembrane perturbation ability than free bile acid salts? This interesting question comes up for discussion. In contrast to free bile acid salts, CBADs have ( $i$ ) a positive charge which may be favorable for approaching to an interaction site of substrates such as vesicles and biomembranes and (ii ) a longer and more flexible chain the length of which is almost the same as that of taurine conjugate bile salt may be easier to enhance the interaction with substrate.

In conclusion, the findings in the present study may be summarized as follws. 1) The surfactant properties of CBADs such as CMC, surface activity and degree of counterion binding to micelles were found almost the same as the respective corresponding sodium salts of free bile acids. 2) The degree of counterion binding $(\beta)$ was not so much dependent on either temperature or CBAD species $(\beta$ values of $\mathrm{EdaDC}$ and $\mathrm{EdaC}$ were about 0.23 and 0.26 , respectively, at the temperature range studied.). 3) The $\Delta G_{\mathrm{m}}^{0}, \Delta H_{\mathrm{m}}^{0}$ and $\Delta S_{\mathrm{m}}^{0}$ values were evaluated respectively. In contribution to the free energy change on micellization, the entropy term is more dominant especially in the lower temperature region than the enthalpy term, but, the contribution degree of the enthalpy term for CBADs is greater than that of common surfactants of linear hydrocarbon chain.
The compensation phenomenon has been clearly observed in the relation of $\Delta S_{\mathrm{m}}^{0}$ with $\Delta H_{\mathrm{m}}^{0}$.

\section{Acknowledgments}

This work was supported in part by the funds from the Central Research Institute, Fukuoka University ; a Grant-in Aid from Scientific Research (C), Ministry of Education, Culture and Science of Japan; and the Foundation of the Science Promotion of Kim Man-Yu. The authors are very grateful to Prof. Moroi, Kyushu University, for his helpful suggestion.

(Received Nov.30, 1998 ; Accepted Jan. 6, 1999)

\section{References}

1) A.F. Hofmann, Hepatology, 4, (Supplement) $4 \mathrm{~S}$ (1984).

2) A. Reuben, Hepatology, 4, (Supplement) $15 \mathrm{~S}$ (1984).

3) G. Sugihara, K. Yamakawa, Y. Murata, M. Tanaka, J. Phys. Chem., 86, 2784 (1982).

4) H. Igimi, M.C. Carey, J. Lipid Res. 22, 254 (1981).

5) M.C. Carey, Hepatology, 4, (Supplement) $138 \mathrm{~S}$ (1984).

6) W.T. Caldwll, (a) J. Am. Chem. Soc., 60, 991 (1938). (b) J. Am. Chem. Soc., 61, 3584 (1939).

7) S.P. James, F. Smith, M. Stacey, M. Webb, J. Am. Chem. Soc., 68, 665 (1946).

8) K. Ziegler, M. Frimmer, H. Fasold, Biochem. Biophys. Acta, 769, 117 (1984).

9) W. De Grip, Methods Enzymol., 81, 256 (1982).

10) Y.I. Araki, S. Lee, G. Sugihara, M. Furuichi, S. Yamashita, F. Ohseto., Colloids Surfaces B: Biointerfaces, 8, 81 (1996).

11) H. Kawamura, Y. Murata, T. Yamaguchi, H. Igimi, M. Tanaka, G. Sugihara, J.P. Kratohvil, $J$. Phys. Chem., 93, 3321 (1989).

12) S. Uryu, M. Aratono, M. Yamanaka, K. Motomura, R. Matuura, Bull. Chem. Soc. Jpn., 57, 976 (1984).

13) J.P. Kratohvil, W.P. Hsu, M.A. Jacobs, T.M. Aminabhavi, Y. Mukunoki, Colloid Polym Sci., 261, 781 (1983).

14) A. Roda, A.F. Hoffman, K.J. Mysels, J. Biolog, Chem., 258, 6362 (1983).

15) K.S. Yamamoto, O. Shibata, M. Sakai, Y. Sasaki, S. Lee, G. Sugihara, Colloids Surface B: Biointerfaces, 5, 249 (1995).

16) H. Miyoshi, S. Nagadome, G. Sugihara, H. Kagimoto, Y. Ikawa, H. Igimi, O. Shibata, J.Colloid Interface Sci., 149, 216 (1992). 
17) K. Shinoda, K. Katsura, J. Phys. Chem., 68, 1568 (1964).

18) P. Mukerjee, J.K. Mysels, Natl. Stand. Ref. Data Ser., Natl. Bur. Stand. No.36 (1971).

19) P. Mukerjee, K. Korematsu, M. Okawauchi, G. Sugihara, J. Phys. Chem., 89, 5308 (1985).

20) G. Sugihara, P. Mukerjee, J. Phys. Chem., 85, 1612 (1981).

21) Y. Moroi, "Micelles Theoretical and Applied Aspects" Plenum Press, New York, (1992).

22) Y. Murata, G. Sugihara, N. Nishikido, M. Tanaka In : "Solution Behavior of Surfactants", (K.L. Mittal, E.J. Fendler, Eds). Vol.1, p.611, Plenum Press. New York, (1982).

23) P. Mukerjee, J. Phys. Chem., 66, 1375 (1962).

24) P. Mukerjee, Adv. Colloid Interface Sci., 1, 241 (1967).

25) E.D. Goddard, G.C. Benson, Can J Chem, 35, 986 (1957).

26) G. Sugihara, Y. Arakawa, K. Tanaka, S. Lee, Y. Moroi, J Colloid Interface Sci, 170, 399 (1995).

27) K. Shinoda, In : "Colloidal Surfactants" (K. Shinoda, T. Nakagawa, B.I. Tamamushi, T. Isemura, Eds.) Academic Press, New York, Chap 1 (1963).

28) Y. Murata, M. Tanaka, G. Sugihara, Fukuoka Univ. Sci. Reports, 17, 23 (1987).
29) J.P. Kratohvil, W.P. Hsu, D.I. Kwok, Langmuir, 2, 256 (1986).

30) R. Vochten, P. Joos, J. Chem. Phys., 67, 1373 (1970).

31) Y. Chang, J.R. Cardinal, J. Pharm. Sci., 67, 994 (1978).

32) E. Racher, J. Biol. Chem., 247, 8198 (1972).

33) (a) N. Funasaki, R. Ueshiba, S. Hada, S. Neya, J. Phys. Chem., 98, 11541 (1994) : for Na-taurocholate (TC) and Na-taurodeoxycholate (TDC)

(b) G. Sugihara, T. Makihara, Y.K. Tanaka, T. Kiyota, T. Nakashima, Fukuoka Univ. Sci. Reports, Vol.29, No.1 (1999), in press : for Nachenodeoxycholate (CDC) and Na-ursodeoxycholate (UDC).

34) H. Sugioka, Y. Moroi, Biochim. Biophys. Acta, 1394, 99 (1998).

35) R. Lumry, S. Rajender, Biopolymeres, 9, 1125 (1970).

36) G. Sugihara, M. Hisatomi, Submitted to J. Colloid Interface Sci.

37) O. Shibata, H. Miyoshi, G. Sugihara, H. Igimi, J. Colloid Interface Sci., 146, 594 (1991).

38) G. Sugihara, K. S. Yamamoto, Y. Yamato, S. Nagadome, S. Lee, Y. Sasaki, O. Shibata, H. Igimi, Colloids Surfaces B: Biointerfaces, 6, 81 (1996). 


\title{
[報文］＼cjkstart各種胆汁酸から合成したカチオン活性剤の ミセル形成に関する熱力学的研究
}

\author{
荒木 洋一・柳田 知倫・久富美保子 \\ 清田 泰良・李＼cjkstart相男・杉原 剛介 \\ 福岡大学理学部化学科（宁814-0180 福岡市城南区七隈 8-19-1)
}

アニオン性界面活性剤の一種である胆汁酸の表面活性やミセル形成などの物性はよく調べられているが, 胆汁酸 の親水基として働く解離基の, 相違に対する依存性について系統的な研究はまだなされていない。そこで，新しい カチオン性胆汁酸誘導体のシリーズ (CBADs); エチレンジアミンモノコラミド塩酸塩 $(\mathrm{EdaC})$, エチレンジアミ ンモノデオキシコラミド塩酸塩 ( $\mathrm{EdaDC})$, エチレンジアミンノノケノデオキシコラミド塩酸塩 $(\mathrm{EdaCDC})$ 及び エチレンジアミンモノウルソデオキシコラミド塩酸塩 (EdaUDC) を合成した。これらの胆汁酸誘導体について, 水溶液中の臨界ミセル濃度 $(\mathrm{CMC})$ や反対イオン結合度 $(\beta)$ などは, 表面張力測定法 (滴容法) を用いて, $10^{\circ} \mathrm{C}$ か ら $50^{\circ} \mathrm{C}$ までの温度範囲内で $10^{\circ} \mathrm{C}$ 刻みに測定を行ない, 決定した。これら合成したカチオン性界面活性剂は, 天然 の胆汁酸のナトリウム塩と比較して生体膜攪乱 (perturbation) 能が高く, 膜透過性も高いが, $\mathrm{CMC}, \beta$ 及び表面 活性などは, $\mathrm{EdaC}$ を除いて天然の胆汁酸と類似していることが分かった。

さらに, 詳細な熱力学的解析を行ない, エントロピーとエンタルピーとの間には, 補償効果が成り立ち, 補償温 度がいすれも約 $300 \mathrm{~K}$ の值を示すことなどを報告する。

(連絡者: 杉原剛介) Vol. 48, No. 4, 307 (1999)

\section{[報文］リポソームの物理化学的特性に及ぼす カルボキシアシルホスファチジルエタノール アミン誘導体の影響}

山内 仁史 ${ }^{* 1} \cdot$ 島崎㦑*1 ・橋崎 要*1

酒井 秀樹 $* 1, * 2$ ・横山 祥子*3 ・ 阿部 正彦 $* 1, * 2$

*1 東京理科大学理工学部 (广278-8510 千葉県野田市山崎 2641)

$* 2$ 東京理科大学界面科研 ( $1162-0825$ 東京都新宿区神楽坂 1-3)

*3 共立薬科大学（干105-8512 東京都港区芝公園 1-5-30)

リポソームの物理化学的特性に及ぼすカルボキシアシルホスファチジルエタノールアミン誘導体 $(\mathrm{CA}-\mathrm{PE})$ の 影響をリポソームのゼー夕電位, 凝集, 相転移温度, 微視的粘性および微視的極性から検討した。その結果, Succinyl-PE あるいは Glutaryl-PE を含むリポソームのゼータ電位の絶対值は, Dodecanyl-PE を含むリポソーム のゼータ電位の絶対值よりも大きかった。また, リポソーム表面付近の二分子膜中の微視的粘性は, DodecanylPE を添加する場合と比べて Succinyl-PE あるいは Glutaryl-PE を添加することによって大きく低下した。こ れらの結果は, Succinyl-PE とGlutaryl-PE の場合にはその極性基部分がリポソーム表面に出ていること，そし て Dodecanyl-PE の場合にはそのカルボキシアシル基の配向状態が他の CA-PE とは異なっていることに起因し ているものと考えられた。アビジン・ビオチン反応に誘起されるリポソームの凝集速度はSuccinyl-PE あるいは Glutaryl-PE を含むりポソームで遅延された。これはリポソーム表面に露出している Succinyl-PE と Glutaryl-PE の親水基がアビジン・ビオチン反応を妨害するような立体的バリアーを形成したためであろうと考えら れた。

(連絡者：阿部正彦) Vol. 48, No. 4, 317 (1999) 